\title{
Manual Validation and Calibration Method for All-or-Nothing Traffic Assignment
}

\author{
Hitapriya Suprayitno ${ }^{1}$
}

\begin{abstract}
Transport Modelling is capital for transportation planning. All-or-Nothing Traffic Assignment is used quite a lot. The model can not be considered valid without passing through validation and calibration process. A validation and calibration method, for the all-or-nothing traffic assignment, need to be developed. The research produced simple practical validation and calibration method. The calculated model traffic volumes are compared against the real traffic volumes. Simple validation method was developed by just setting a maximum allowable error, measured in precentage. Simple calibration method consists of correcting the model traffic volume by correcting the corresponding OD Matrix cell values. The calibration consists of 4 basic tasks $: 1$. identifying the traffic volume need to be calibrated, 2. identifying corresponding $O D$ matrix cells corresponding to the traffic volume need to be calibrated, 3. distributing traffic volume error to the coresponding $O D$ matrix cells, and 4. developing the calibrated $O D$ matrix. Validation and Calibration are a pair of an iterative process.
\end{abstract}

Keywords - transportation modelling, all-or-nothing traffic assignment, validation, calibration.

\section{INTRODUCTION}

A regions Transportation Master Plan need to be developed periodically. For this purpose a Region Transport Model need to be developed to be used as a foundation for transportation planning [1].

Even if the basic of Transportation Modelling is the Four Steps, it vary in applications, depend on the case. The three general types are direct, conventional and unconventional model. While in terms of Traffic Assignment, among others, there are all-or-nothing, incremental loading, and equilibrium type [5,10].

All-or-Nothing Traffic Assignment phenomena are still widely occured. The freight truck network, the sparse road network, all of these function as an All-or-Nothing Traffic Assignment. Its calculation is easier and can be done without using special software $[5,7,8,9,10,12]$.

Certain Transportation Modelling Software, such as Visum and EMME/IV, have facilities to execute validation and calibration calculation. But, these facilities are not specially designated for the validation and calibration. Besides, these kind of softwares are onerous enough. Therefore, those are not easily accessible $[4,5,8]$.

It is impossible to be able to develop a model without error. Modelling result need to be validated and calibrated. Major transportation model validation and calibration can be done only after the final step, upon the calculated model traffic volume $[2,3,5,7,9,12,13,14]$.

Transportation Modelling methods have been dicussed quite a lot in courseworks, handbooks, scientific papers, researches and studies. On the other hand, the validation

\footnotetext{
${ }^{1}$ Hitapriya Suprayitno is with Department of Civil Engineering, Institut Teknologi Sepuluh Nopember, Surabaya, Indonesia. E-mail: suprayitno.hita@gmail.com; hitapriya@ce.its.ac.id.
}

and calibration method are still rarely discussed and developed. Meanwhile, these two are obligation for professional transportation modelling work $[4,5,6,7,8,9,12]$.

Therefore manual validation and calibration method, for All-or-Nothing Traffic Assignment, need to be developed. This paper present an attempt to develop the method. This research deals only with OD Matrix error.

\section{METHOD}

\section{A. Transportation Modelling}

Transportation Modelling in general means an Area Wide Transportation Supply-Demand Modelling. This modelling technic can be used for all kind of modes, either for passenger or freight, and either for public or private transportation. Basically, the transportation modelling consists of four steps. But, in general, this can be grouped into three basic types : direct, conventional and unconventional modelling. The four steps known as : trip generation, modal split, trip distribution and traffic assignment. The suite of these four can vary, but the trip generation is always the starter point and the traffic assignment is always the end point. The fourth step, traffic assignment, knows several types : all-or-nothing, incremental loading, equilibrium an others. There are varieties of model for each step. Result validation can only be executed in the end, upon calculated link traffic volume $[5,12]$.

\section{B. Validation and Calibration}

Validation is to verify wether the modelling result is valid or not. Valid means the error occured are acceptable. Calibration means to correct the unacceptable error of modelling result to achieve acceptable error condition. Validation and calibration are iteratives process. The error types are : measurement, sample, calculation and specification error. In engineering design, we can find a lot of validation measured in comparaison of the result value to the expected value. The accepted difference can be measured in precentage number. Thus, one of the simplest validation method is by defining a threshold of acceptable error [3,13].

In Transportation Modelling, validation and calibration deal with assessing the calculated traffic volume value as a result of modelling process, compared these to the real values $[2,14]$.

\section{Special Matrix Technic}

A Special Matrix Technic has ever been developed for Transportation Network Analysis. This technic has been proofed to be practical and efficient to be used for Road Network Analysis Calculation [8,11]. 


\section{CONCEPT DEVELOPMENT}

\section{A. Basic Concept}

Traffic Assignment is a resultat of calculation to assign OD Matrix to the network under a certain calculation method. Therefore it is clear, as also indicated by personal experience and assuming that there is no error in calculation process, that error resources can be from : the Traffic Assignment Model, the OD Matrix Model and the Network Model. The network model error itself can consist of errors on the link model, the node model, the centroid model and the connector models.

Thus calibration is a complicated work. This research is restricted only to deal with OD Matrix error.

\section{B. General Method}

Validation and Calibration is a pair of an iterative correction work. The model calculation result first has to be validated. Those which are not valid than has to be calibrated. Afterward the validation has to be executed again. This iterative work has to be executed until a reasonable or satisfying model result will have been gotten. The iterative process is presented in Figure 1 below.

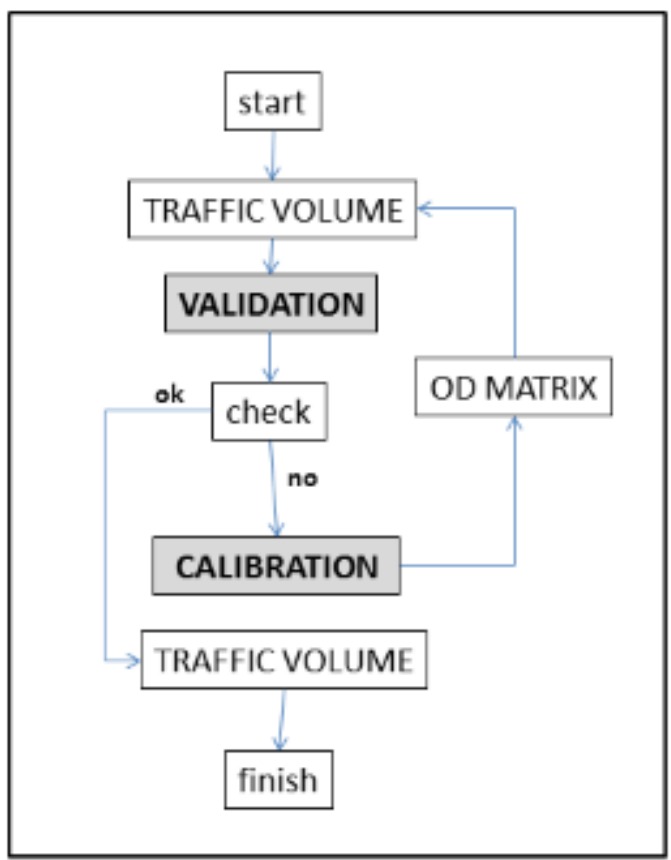

Figure 1. Iterative Validation and Calibration

\section{Simple Case for Method Development}

For Method Development a Simple Case is needed to make Method Development clear and simple. A network consists of 3 nodes and 3 links is taken. The network and the OD Matrix are presented in Figure 2 and Table 1 below.

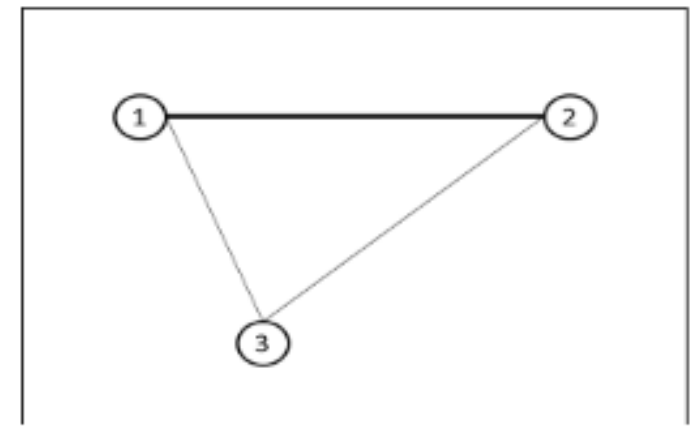

Figure 2. Simple Case Network

TABLE 1.

THE SIMPLE CASE OD MATRIX

\begin{tabular}{|c|c|c|c|}
\hline OD & $\mathbf{1}$ & $\mathbf{2}$ & $\mathbf{3}$ \\
\hline $\mathbf{1}$ & 0 & 15 & 23 \\
\hline $\mathbf{2}$ & 17 & 0 & 17 \\
\hline $\mathbf{3}$ & 32 & 12 & 0 \\
\hline
\end{tabular}

Model Traffic Volume were calculated afterward based on the Network and the OD Matrix. The All-or-Nothing Traffic Assignment calculation is presented in Table 2 below.

TABLE 2.

TRAFFIC ASSIGNMENT CALCULATION

\begin{tabular}{|c|c|c|c|c|c|c|c|c|}
\hline \multirow{3}{*}{ No } & \multirow{3}{*}{ Link } & \multicolumn{6}{|c|}{ OD } & \multirow{3}{*}{ Traffic } \\
\hline & & 1-2 & 1-3 & 2-1 & $2-3$ & 3-1 & 3-2 & \\
\hline & & 15 & 23 & 17 & 17 & 32 & 12 & \\
\hline 1 & $1-2$ & 15 & & & & & & 15 \\
\hline 2 & $2-1$ & & & 17 & & & & 17 \\
\hline 3 & $1-3$ & & 23 & & & & & 23 \\
\hline 4 & 3-1 & & & & & 32 & & 32 \\
\hline 5 & $2-3$ & & & & 17 & & & 17 \\
\hline 6 & 3-2 & & & & & & 12 & 12 \\
\hline
\end{tabular}

Furthermore, the Model Traffic Volume and the Real Traffic Volume are presented graphically in Figure 3 and Figure 4 as follows.

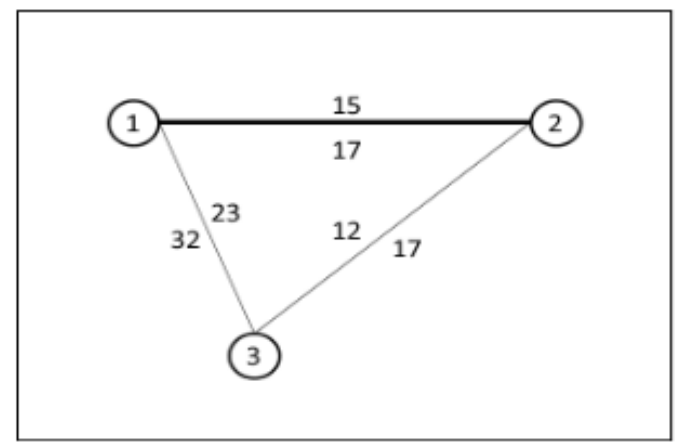

Figure 3. Model Traffic Flow 


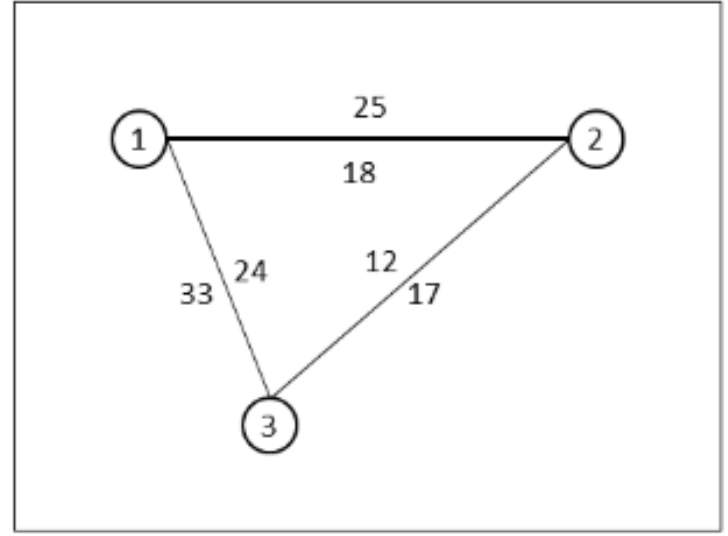

Figure 4. Real Traffic Flow

As an example, the Real Traffic Flow is also presented in a matrix form in Table 3 as follows.

TABLE 3.

REAL TRAFFIC FlOW MATRIX

\begin{tabular}{|c|c|c|c|}
\hline TF & 1 & 2 & 3 \\
\hline 1 & 0 & 25 & 24 \\
\hline 2 & 18 & 0 & 17 \\
\hline 3 & 33 & 12 & 0 \\
\hline
\end{tabular}

\section{Validation Method Development}

For practicality reason, Validation is assessed based on maximum allowable error, measure in precentage. A maximum allowable error of 5\%-10\% seems rasonable, depends on the case.

Example of Simple Case Validation Calculation was made with a $10 \%$ maximum allowable error. The calculation is presented in Table 4 below.

TABLE 4.

VALIDATION CALCULATION

\begin{tabular}{|c|c|c|c|c|c|c|}
\hline \multirow{2}{*}{ No } & \multirow{2}{*}{ Link } & \multicolumn{2}{|c|}{ Traffic Volume } & \multicolumn{2}{|c|}{ Error } & \multirow{2}{*}{ Eval. } \\
\cline { 3 - 6 } & & Real & Model & Value & $\%$ & \\
\hline 1 & $1-2$ & 25 & 15 & -10 & $-40,0$ & X \\
\hline 2 & $2-1$ & 18 & 17 & -1 & $-5,6$ & ok \\
\hline 3 & $1-3$ & 24 & 23 & -1 & $-4,2$ & ok \\
\hline 4 & $\mathbf{3}-1$ & $\mathbf{3 3}$ & $\mathbf{3 2}$ & -1 & $-\mathbf{3 , 0}$ & ok \\
\hline 5 & $\mathbf{2 - 3}$ & $\mathbf{1 7}$ & $\mathbf{1 7}$ & $\mathbf{0}$ & $\mathbf{0 , 0}$ & ok \\
\hline 6 & $\mathbf{3}-2$ & $\mathbf{1 2}$ & $\mathbf{1 2}$ & $\mathbf{0}$ & $\mathbf{0 , 0}$ & ok \\
\hline
\end{tabular}

Traffic Volume on Link 1-2 has significant error value. It needs to be calibrated.

The validation calculation can be made by comparing two traffic flow matrix, i.e the real traffic flow against the model traffic flow. An example of traffic flow matrix can be regarded in Table 3 above. This calculation method seems more complex and less practical, for this case.

The special matrix technic calculation, even if it is part of this research, is not discussed in this paper.

\section{E. Calibration Method Development}

Calibration method is developed based on the basic principle that a calculated traffic flow is a special addition of certain OD matrix cell values $[1,2,4,5,6]$. Therefore for this case, correcting the calculated traffic volumes have to be done by changing the related OD Matrix cell values.

The method consists of : 1 . identifying the traffic flow with unacceptable error and its error value, 2 . identifying the OD Cells participating in the traffic flow with significant error, 3 . correcting the OD Cells value by distributing the error value proportionally to the related cells values, 4. calculating the Calibrated OD Matrix.

Step 1 can be represented by Table 4 above. Traffic Flow on Link 1-2 experience unacceptable error, with a value of 10 . Afterward step 2 can be represented by Table 2 above. The OD Cell participating in Flow on Link 1-2 is the Cel 1-2 $\left(\mathrm{T}_{12}\right)$.

Calibration then can be executed. The Calibration Calulation is presented in Table 5 below. Model Traffic Volume and Real Traffic Volume is compared, give an error of 10 . The error of 10 then is used for Cell 1-2 correction or is distributed only to Cell 1-2. This action give result of a new value of 25 .

TABLE 5 .

Calibration Calculation

\begin{tabular}{|c|c|c|c|c|c|c|c|c|}
\hline \multirow{2}{*}{ No } & \multirow{7}{*}{ Link } & $\mathbf{1 - 2}$ & $\mathbf{1 - 3}$ & $\mathbf{2 - 1}$ & $\mathbf{2 - 3}$ & $\mathbf{3 - 1}$ & $\mathbf{3 - 2}$ & \multirow{2}{*}{ Traffic } \\
\cline { 2 - 9 } & & 15 & 23 & 17 & 17 & 32 & 12 & \\
\hline 1 & $1-2$ & 15 & & & & & & 15 \\
\hline \multicolumn{2}{|c|}{ Real TV } & & & & & & & 25 \\
\hline \multicolumn{2}{|c|}{ Correction } & 10 & & & & & & 10 \\
\hline New OD Val. & 25 & & & & & & \\
\hline
\end{tabular}

The calibration calculation gives a Calibrated OD Matrix, which is presented in Table 6 below.

TABLE 6 .

TABLE 6.
\begin{tabular}{|c|c|c|c|}
\hline CD & $\mathbf{1}$ & $\mathbf{2}$ & $\mathbf{3}$ \\
\hline $\mathbf{1}$ & 0 & 25 & 23 \\
\hline $\mathbf{2}$ & 17 & 0 & 17 \\
\hline $\mathbf{3}$ & 32 & 12 & 0 \\
\hline
\end{tabular}

\section{F. Method Development Resume}

The Validation and Calibation Method Development has been finished. The iterative process is not necessary to be explained here.

Calibration Calculation Table basically the same as Traffic Assignmnet Table with a slight modification and row addition to calculate the distribution of error value to the related OD Matrix Cells.

\section{METHOD TRIAL}

\section{A. Trial Case}

One of the All-or-Nothing Traffic Assignment Network in Surabaya is the 40' Container Semi- Trailer Truck Routes Network. This was taken as the trial case. The network is presented in Figure 5 below. 


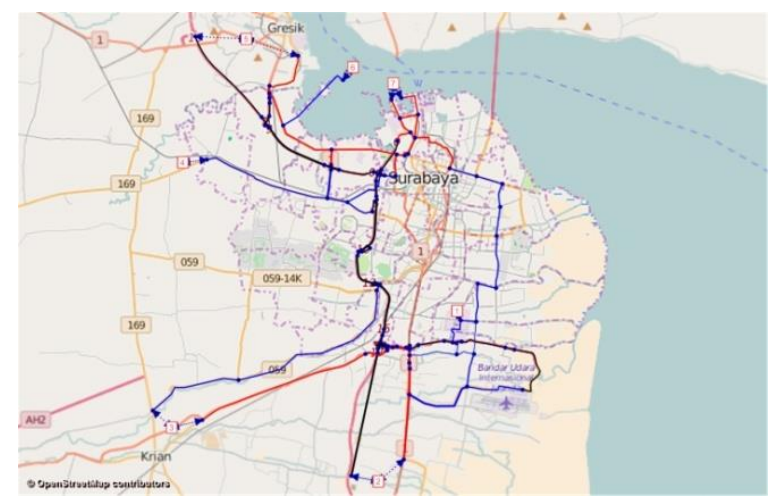

Figure 5 .The Surabaya Truck Route Network

For the purpose of simplicity, clarity and easiness of the Method Trial calculation, the truck route network is again very simplified, which consists only of 5 traffic zones and 6 links. The Trial Network is presented in Figure 6 below.

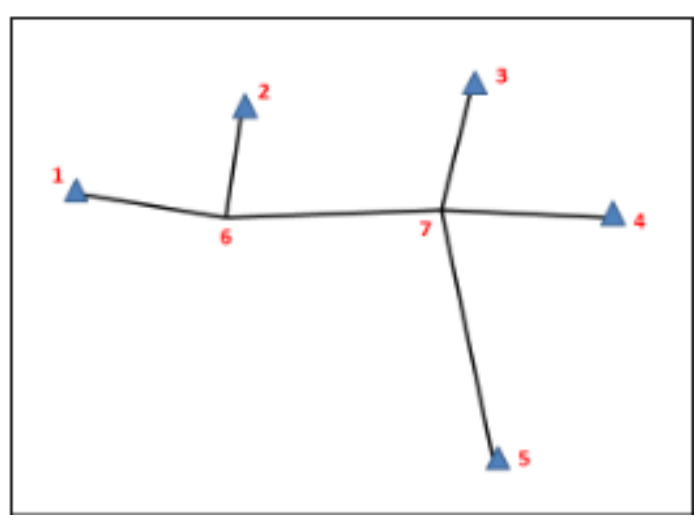

Figure 6 .Simplified Truck Route Network Model

Afterward, a set of imaginary real traffic volume on each link were defined. The imaginary real traffic volume is presented graphically in Figure 7 as follows.

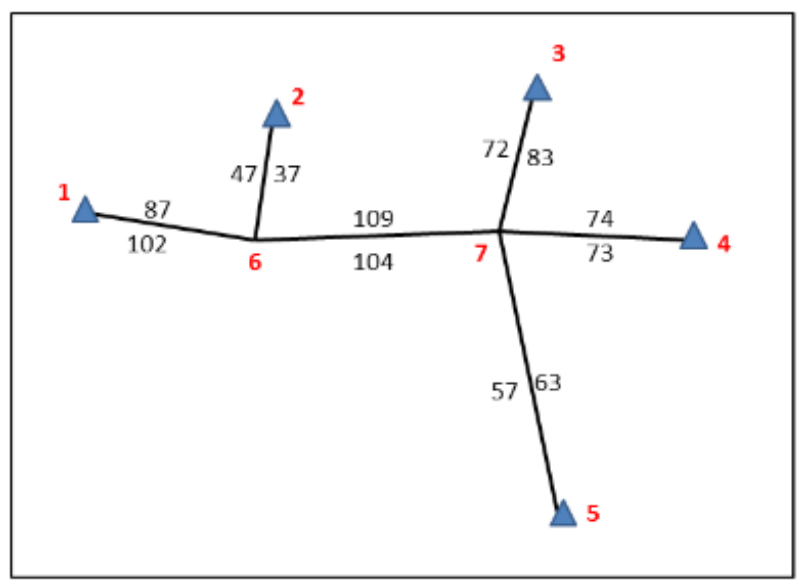

Figure 7. Real Traffic Volume

The last thing to be defined for the Method Trial Network Case is the imaginary OD Matrix Data, as a result of an imaginary modelling work. The imaginary OD Matrix is presented in Table 7 as follows.

TABLE 7.

IMAGINARY ORIGIN DESTINATION MATRIX

\begin{tabular}{|c|c|c|c|c|c|}
\hline OD & $\mathbf{1}$ & $\mathbf{2}$ & $\mathbf{3}$ & $\mathbf{4}$ & $\mathbf{5}$ \\
\hline $\mathbf{1}$ & 0 & 14 & 21 & 32 & 19 \\
\hline $\mathbf{2}$ & 16 & 0 & 7 & 11 & 14 \\
\hline $\mathbf{3}$ & 32 & 8 & 0 & 21 & 23 \\
\hline $\mathbf{4}$ & 41 & 9 & 19 & 0 & 6 \\
\hline $\mathbf{5}$ & 17 & 8 & 24 & 9 & 0 \\
\hline
\end{tabular}

\section{B. Traffic Assignment}

The first thing to be calculated is the Traffic Assignment. The Traffic Assignment Calculation table is presented in this paper, since it will be used for Calibration purpose. The Traffic Assignment Calculation is presented in Table 8 as follows. The Traffic Assignment Result, called as Model Traffic Volume, is presented graphically in Figure 8 below.

TABLE 8.

TRAFFIC ASSIGNMENT CALCULATION

\begin{tabular}{|c|c|c|c|c|c|c|c|c|c|c|c|c|c|c|c|c|c|c|c|c|c|c|}
\hline \multirow{3}{*}{ No } & \multirow{3}{*}{ Link } & \multicolumn{20}{|c|}{ OD } & \multirow{3}{*}{ Traffic } \\
\hline & & 12 & 13 & 14 & 15 & 21 & 23 & 24 & 25 & 31 & 32 & 34 & 35 & 41 & 42 & 43 & 45 & 51 & 52 & 53 & 54 & \\
\hline & & 14 & 21 & 32 & 19 & 16 & 7 & 11 & 14 & 32 & 8 & 21 & $\mathbf{2 3}$ & 41 & 9 & 19 & 6 & 17 & 8 & 24 & 9 & \\
\hline 1 & $1-6$ & 14 & 21 & 32 & 19 & & & & & & & & & & & & & & & & & 86 \\
\hline 2 & 6-1 & & & & & 16 & & & & 32 & & & & 41 & & & & 17 & & & & 106 \\
\hline 3 & $2-6$ & & & & & 16 & 7 & 11 & 14 & & & & & & & & & & & & & 48 \\
\hline 4 & $6-2$ & 14 & & & & & & & & & 8 & & & & 9 & & & & 8 & & & 39 \\
\hline 5 & $3-7$ & & & & & & & & & 32 & 8 & 21 & $\mathbf{2 3}$ & & & & & & & & & 84 \\
\hline 6 & $7-3$ & & 21 & & & & 7 & & & & & & & & & 19 & & & & 24 & & $\pi 1$ \\
\hline 7 & $4-7$ & & & & & & & & & & & & & 41 & 9 & 19 & 6 & & & & & 5 \\
\hline 8 & $7-4$ & & & 32 & & & & 11 & & & & 21 & & & & & & & & & 9 & 73 \\
\hline 9 & 5-7 & & & & & & & & & & & & & & & & & 17 & 8 & 24 & 9 & 58 \\
\hline 10 & $7-5$ & & & & 19 & & & & 14 & & & & $\mathbf{2 3}$ & & & & 6 & & & & & 62 \\
\hline 11 & $6-7$ & & 21 & 32 & 19 & & 7 & 11 & 14 & & & & & & & & & & & & & 104 \\
\hline 12 & $7-6$ & & & & & & & & & 32 & 8 & & & 41 & 9 & & & 17 & 8 & & & 115 \\
\hline
\end{tabular}




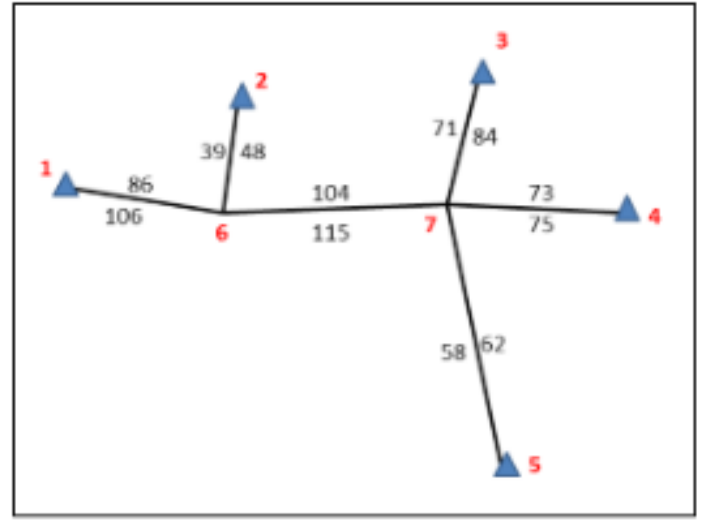

Figure 8. Model Traffic Volume

\section{Validation}

The Model and Real Traffic Volumes have been gotten already. Validation can be then executed. A maximum allowable error of $5 \%$ is taken. It can be noted that there are two traffic volumes having unacceptable error, i.e. : the traffics in Link 7-6 and Link 6-2. The validation calculation is presented in Table 9 below.

TABLE 9.

VALIDATION CALCULATION

\begin{tabular}{|c|c|c|c|c|c|c|}
\hline \multirow{2}{*}{ No } & \multirow{2}{*}{ Link } & \multicolumn{2}{|c|}{ Traffic } & \multicolumn{2}{|c|}{ Error } & \multirow{2}{*}{ Eval. } \\
\cline { 3 - 6 } & & Real & Model & Value & $\%$ & \\
\hline $\mathbf{1}$ & $\mathbf{1 - 6}$ & $\mathbf{8 7}$ & $\mathbf{8 6}$ & $-\mathbf{1}$ & $\mathbf{- 1 , 1}$ & ok \\
\hline $\mathbf{2}$ & $\mathbf{6 - 1}$ & $\mathbf{1 0 2}$ & $\mathbf{1 0 6}$ & $\mathbf{4}$ & $\mathbf{3 , 9}$ & ok \\
\hline $\mathbf{3}$ & $\mathbf{2 - 6}$ & $\mathbf{4 7}$ & $\mathbf{4 8}$ & $\mathbf{1}$ & $\mathbf{2 , 1}$ & ok \\
\hline 4 & $6-2$ & 37 & 39 & 2 & 5,4 & error \\
\hline $\mathbf{5}$ & $\mathbf{3 - 7}$ & $\mathbf{8 3}$ & $\mathbf{8 4}$ & $\mathbf{1}$ & $\mathbf{1 , 2}$ & ok \\
\hline $\mathbf{6}$ & $\mathbf{7 - 3}$ & $\mathbf{7 2}$ & $\mathbf{7 1}$ & $-\mathbf{1}$ & $\mathbf{- 1 , 4}$ & ok \\
\hline $\mathbf{7}$ & $\mathbf{4 - 7}$ & $\mathbf{7 3}$ & $\mathbf{7 5}$ & $\mathbf{2}$ & $\mathbf{2 , 7}$ & ok \\
\hline $\mathbf{8}$ & $\mathbf{7 - 4}$ & $\mathbf{7 4}$ & $\mathbf{7 3}$ & $-\mathbf{1}$ & $\mathbf{- 1 , 4}$ & ok \\
\hline $\mathbf{9}$ & $\mathbf{5 - 7}$ & $\mathbf{5 7}$ & $\mathbf{5 8}$ & $\mathbf{1}$ & $\mathbf{1 , 8}$ & ok \\
\hline $\mathbf{1 0}$ & $\mathbf{7 - 5}$ & $\mathbf{6 3}$ & $\mathbf{6 2}$ & $-\mathbf{1}$ & $\mathbf{- 1 , 6}$ & ok \\
\hline $\mathbf{1 1}$ & $\mathbf{6 - 7}$ & $\mathbf{1 0 9}$ & $\mathbf{1 0 4}$ & $-\mathbf{5}$ & $\mathbf{- 4 , 6}$ & ok \\
\hline 12 & $7-6$ & 104 & 115 & 11 & 10,6 & error \\
\hline
\end{tabular}

\section{Calibration}

Since the Validation has been executed, the Calibration can be started now.
The Calibration consists of 4 steps : 1 . identifying the traffics need to be calibrated, 2. identifying the OD Matrix Cells need to be calibrated, 3 . distributing traffic volume error to the related OD Matrix Cells, and 4. Distributing the Calibrated OD Matrix. The four steps will be done one by one below.

The first step, identifying traffic flow need to be calibrated is done and is presented in Table 10 below. It can be noted that Traffic Volume in Link 7-6 and Link 62 need to be calibrated. Since the error for Link 7-6 is more important, calibration is made for Link 7-6 first. The calibration will be continued for Link 6-2 if necessary.

TABLE 10

IDENTIFICATION OF CALIBRATED TRAFFIC

\begin{tabular}{|c|c|c|c|c|c|c|c|}
\hline \multirow{2}{*}{ No } & \multirow{2}{*}{ Link } & \multicolumn{2}{|c|}{ Traffic } & \multicolumn{2}{c|}{ Error } & \multirow{2}{*}{ Eval. } & \multirow{2}{*}{$\begin{array}{c}\text { Need } \\
\text { Calibration }\end{array}$} \\
\cline { 3 - 6 } & & Real & Model & Value & $\%$ & & \\
\hline $\mathbf{1}$ & $\mathbf{1 - 6}$ & $\mathbf{8 7}$ & $\mathbf{8 6}$ & $-\mathbf{1}$ & $\mathbf{- 1 , 1}$ & ok & \\
\hline $\mathbf{2}$ & $\mathbf{6 - 1}$ & $\mathbf{1 0 2}$ & $\mathbf{1 0 6}$ & $\mathbf{4}$ & $\mathbf{3 , 9}$ & ok & \\
\hline $\mathbf{3}$ & $\mathbf{2 - 6}$ & $\mathbf{4 7}$ & $\mathbf{4 8}$ & $\mathbf{1}$ & $\mathbf{2 , 1}$ & ok & \\
\hline 4 & $6-2$ & 37 & 39 & 2 & 5,4 & error & need calib 2 \\
\hline $\mathbf{5}$ & $\mathbf{3 - 7}$ & $\mathbf{8 3}$ & $\mathbf{8 4}$ & $\mathbf{1}$ & $\mathbf{1 , 2}$ & ok & \\
\hline $\mathbf{6}$ & $\mathbf{7 - 3}$ & $\mathbf{7 2}$ & $\mathbf{7 1}$ & $-\mathbf{1}$ & $\mathbf{- 1 , 4}$ & ok & \\
\hline $\mathbf{7}$ & $\mathbf{4 - 7}$ & $\mathbf{7 3}$ & $\mathbf{7 5}$ & $\mathbf{2}$ & $\mathbf{2 7}$ & ok & \\
\hline $\mathbf{8}$ & $\mathbf{7 - 4}$ & $\mathbf{7 4}$ & $\mathbf{7 3}$ & $-\mathbf{1}$ & $\mathbf{- 1 , 4}$ & ok & \\
\hline $\mathbf{9}$ & $\mathbf{5 - 7}$ & $\mathbf{5 7}$ & $\mathbf{5 8}$ & $\mathbf{1}$ & $\mathbf{1 , 8}$ & ok & \\
\hline $\mathbf{1 0}$ & $\mathbf{7 - 5}$ & $\mathbf{6 3}$ & $\mathbf{6 2}$ & $-\mathbf{1}$ & $\mathbf{- 1 , 6}$ & ok & \\
\hline $\mathbf{1 1}$ & $\mathbf{6 - 7}$ & $\mathbf{1 0 9}$ & $\mathbf{1 0 4}$ & $-\mathbf{5}$ & $\mathbf{- 4 , 6}$ & ok & \\
\hline 12 & $7-6$ & 104 & 115 & 11 & 10,6 & error & need calib 1 \\
\hline
\end{tabular}

The step 2 can be done afterward. Identifying the OD Matrix Cells need to be Calibrated is presented in Table 11 below. The Table 11 is in fact the Traffic Assignment Calculation table. Here, the corresponding cell values to the calibrated traffic volume (Link 1-2) are searched. The process indicate that Cells number 31, 32, 41, 42, 51 and 52 need to be calibrated.

Since step 2 has been finished, step 3 Distributing Traffic Volume Error to Related OD Cells can be done. The calculation is made first for Traffic Volume on Link 7-6. The error is distributed to 6 OD Matrix Cells identified above. The Calibration Calculation is done and is presented in Table 12 as follow. The values of six OD Matrix Cells has been modified into 29, 7, 37, 8, 15 and 7 respectively for Cells number 31, 32, 41, 42, 51 and 52 .

TABLE 12.

THE CALibration CALCULATiON

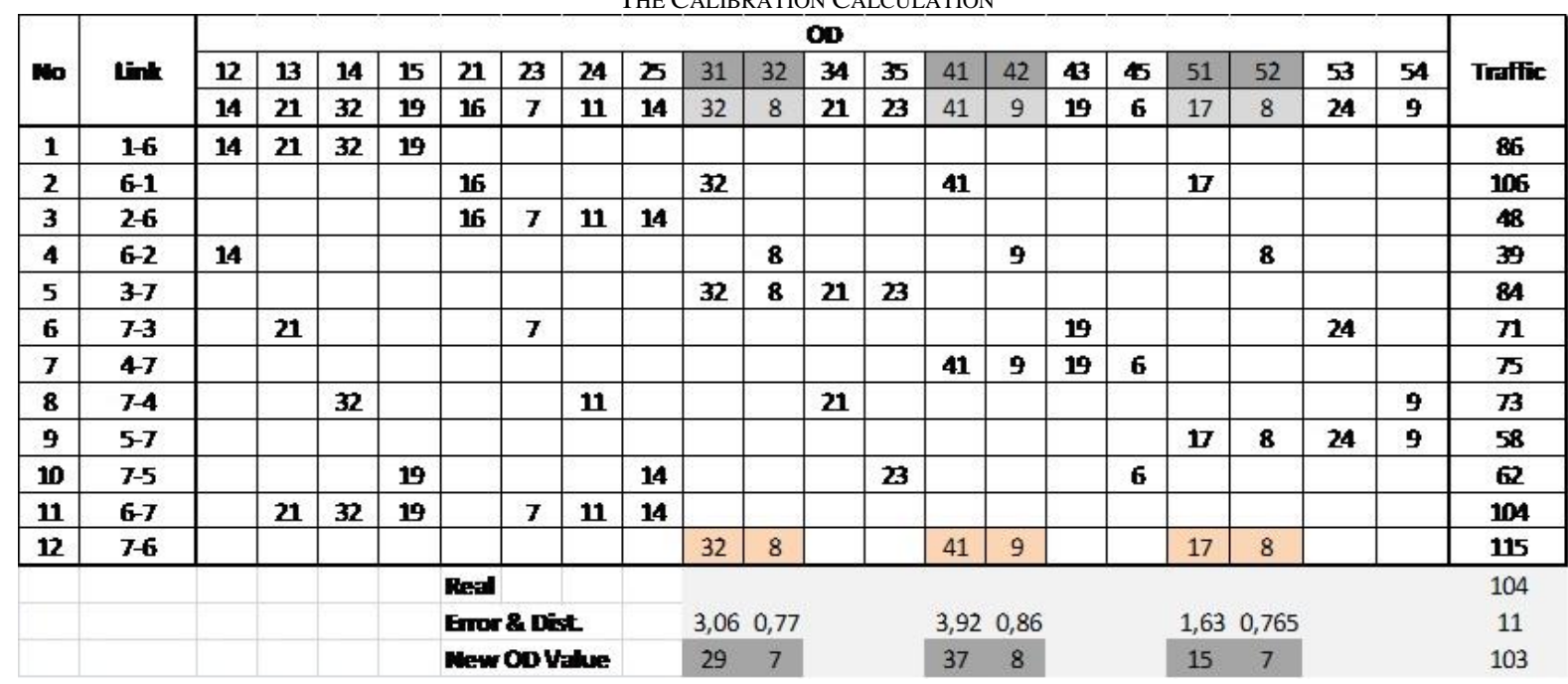


Now since step 3 has been finished, the final step, the step 4 can be done. The step 4 consists of developing the Calibrated OD Matrix. The calibrated cells are cells : 31 , 32, 41, 42, 51 and 52. Calibrated OD Matrix is presented in Table 13 below.

TABLE 13

CALIBRATED OD MATRIX

\begin{tabular}{|c|c|c|c|c|c|}
\hline OD & 1 & 2 & 3 & 4 & 5 \\
\hline 1 & 0 & 14 & 21 & 32 & 19 \\
\hline 2 & 16 & 0 & 7 & 11 & 14 \\
\hline 3 & 29 & 7 & 0 & 21 & 23 \\
\hline 4 & 37 & 8 & 19 & 0 & 6 \\
\hline 5 & 15 & 7 & 24 & 9 & 0 \\
\hline
\end{tabular}

\section{E. Final Validation}

Finally, a Final Validation has to be done to verify wether the calibration is already satisfying or not.

For this purpose a traffic assignment has to be execute to produce Calibrated Model Traffic Volume. The calibration modified 6 traffic volume on Links : 6-1, 6-2, 3-7, 4-7, 5-7 and 7-6.

The traffic assignment calculation is presented in Table 14 below.

TABLE 14.

NEW TRAFFIC ASSIGNMENT CALCULATION

\begin{tabular}{|c|c|c|c|c|c|c|c|c|c|c|c|c|c|c|c|c|c|c|c|c|c|c|}
\hline \multirow{3}{*}{ No } & \multirow{3}{*}{ Ink } & \multicolumn{20}{|c|}{ OD } & \multirow{3}{*}{ Traffic } \\
\hline & & 12 & 13 & 14 & 15 & 21 & 23 & 24 & $\mathbf{5}$ & 31 & 32 & 34 & 35 & 41 & 42 & 43 & 8 & 51 & 52 & 53 & 54 & \\
\hline & & 14 & 21 & 32 & 19 & 16 & 7 & 11 & 14 & 29 & 7 & 21 & 23 & 37 & 8 & 19 & 6 & 15 & 7 & 24 & 9 & \\
\hline 1 & $1-6$ & 14 & 21 & 32 & 19 & & & & & & & & & & & & & & & & & 86 \\
\hline 2 & 6-1 & & & & & 16 & & & & $\boldsymbol{\gamma}$ & & & & 37 & & & & 15 & & & & 97 \\
\hline 3 & 26 & & & & & 16 & 7 & 11 & 14 & & & & & & & & & & & & & 48 \\
\hline 4 & 6-2 & 14 & & & & & & & & & 7 & & & & 8 & & & & 7 & & & 36 \\
\hline 5 & $3-7$ & & & & & & & & & 20 & 7 & $\mathbf{n}$ & 23 & & & & & & & & & 80 \\
\hline 6 & $7-3$ & & $\mathbf{n}$ & & & & 7 & & & & & & & & & 19 & & & & 24 & & $n$ \\
\hline 7 & 47 & & & & & & & & & & & & & 37 & 8 & 19 & 6 & & & & & $\pi$ \\
\hline 8 & $7-4$ & & & 32 & & & & 11 & & & & $\mathbf{z 1}$ & & & & & & & & & 9 & $\mathbf{7 3}$ \\
\hline 9 & $5-7$ & & & & & & & & & & & & & & & & & 15 & 7 & 24 & 9 & $\mathbf{5}$ \\
\hline 10 & $7-5$ & & & & 19 & & & & 14 & & & & $\mathbf{2 3}$ & & & & 6 & & & & & 6. \\
\hline 11 & $6-7$ & & 21 & 32 & 19 & & 7 & 11 & 14 & & & & & & & & & & & & & 104 \\
\hline 12 & $7-6$ & & & & & & & & & 29 & 7 & & & 37 & 8 & & & 15 & 7 & & & 108 \\
\hline
\end{tabular}

This final traffic assignment result is presented graphically in Figure 9 below.

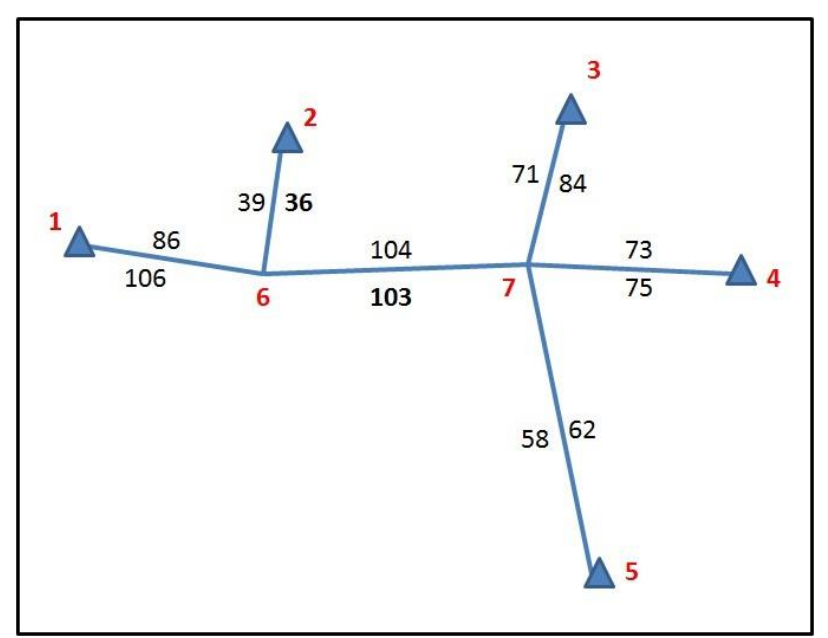

Figure 9 Calibrated Model Traffic Volume

The Calibrated Model Traffic Volume can be presented in a matrix form, as presented in Table 15 below.
TABEL 15 .

CALiBrated Model TRAFFiC Volume Matrix

\begin{tabular}{|c|c|c|c|c|c|c|c|}
\hline TF & $\mathbf{1}$ & $\mathbf{2}$ & $\mathbf{3}$ & $\mathbf{4}$ & $\mathbf{5}$ & $\mathbf{6}$ & $\mathbf{7}$ \\
\hline $\mathbf{1}$ & 0 & 0 & 0 & 0 & 0 & 86 & 0 \\
\hline $\mathbf{2}$ & 0 & 0 & 0 & 0 & 0 & 36 & 0 \\
\hline $\mathbf{3}$ & 0 & 0 & 0 & 0 & 0 & 0 & 84 \\
\hline $\mathbf{4}$ & 0 & 0 & 0 & 0 & 0 & 0 & 75 \\
\hline $\mathbf{5}$ & 0 & 0 & 0 & 0 & 0 & 0 & 58 \\
\hline $\mathbf{6}$ & 106 & 39 & 0 & 0 & 0 & 0 & 104 \\
\hline $\mathbf{7}$ & 0 & 0 & 71 & 73 & 62 & 103 & 0 \\
\hline
\end{tabular}

After calibrated traffic volume has been gotten, the Final Validation can be executed. The Final Validation indicates that all Calibrated Traffic Volumes are satisfying, with all error values are less than 5\%. The Final Validation is presented in Table 16 below. 
TABEL 16.

VALIDATION FOR CALIBRATED TRAFFIC

\begin{tabular}{|c|c|c|c|c|c|c|}
\hline \multirow{2}{*}{ No } & \multirow{2}{*}{ Link } & \multicolumn{2}{|c|}{ Traffic } & \multicolumn{2}{|c|}{ Error } & \multirow{2}{*}{ Eval. } \\
\hline & & Real & Model & Value & $\%$ & \\
\hline 1 & $1-6$ & 87 & 86 & -1 & $-1,1$ & ok \\
\hline 2 & $6-1$ & 102 & 97 & -5 & $-4,9$ & ok \\
\hline 3 & $2-6$ & 47 & 48 & 1 & $\mathbf{2 , 1}$ & ok \\
\hline 4 & $6-2$ & 37 & 36 & -1 & $-2,7$ & ok \\
\hline 5 & $3-7$ & 83 & 80 & -3 & $-3,6$ & ok \\
\hline 6 & $7-3$ & $\pi$ & $\pi 1$ & -1 & $-1,4$ & ak \\
\hline 7 & $4-7$ & 73 & $\pi$ & -3 & $-4,1$ & ok \\
\hline 8 & $7-4$ & 74 & 73 & -1 & $-1,4$ & ak \\
\hline 9 & 5-7 & 57 & 55 & -2 & $-3,5$ & ok \\
\hline 10 & $7-5$ & 63 & 62 & -1 & $-1,6$ & ok \\
\hline 11 & $6-7$ & 109 & 104 & -5 & $-4,6$ & ok \\
\hline 12 & $7-6$ & 104 & 103 & -1 & $-1,0$ & ok \\
\hline
\end{tabular}

\section{F. Method Trial Resume}

Method Trial has been sucessfully executed. The Method Trial indicate that the Manual Validation and Calibration Method can be used easily.

It must be noted that Validation Method by applying a value of acceptable error, measured in precentage is very practical, yet appropriate.

It must be noted also that Four Steps Calibration Calculation Method is also very appropriate, practical, simple and clear. The calibration calculation must be started on Link with biggest error downward.

The Special Matrix Technic is not used in this paper for practical reason, cause it takes longer and more complicated text. Nevertheless, the Special Matrix Technic is used for presenting OD Matrix and Traffic Volume Matrix in Table 5, Table 6, Table 12 and Table 14 above.

By chance the Trial Case needs only 1 Calibration Calculation. It must be noted that different case may needs more than one Calibration Calculation.

\section{CONCLUSION}

Research objective has been attained. The Manual Validation and Calibration Method for All-or-Nothing Traffic Assignment has been succesfully developed.

The Validation Method is about verifying wether the Model Traffic Volume do not differ so much from the real value. It can be done by applying maximum error value, measured in precentage.

The Calibration Method is about changing the Model Traffic Volume. The calibration method is based on the basic concept that Traffic Volume is a special addition of OD Matrix Cell values. Therefore, calibration is done by correcting the OD Matrix Cell values, which are corresponding to the Traffic Volume needs to be calibrated. The correction value is equal to the traffic volume error value, distributed to the all corersponding cells proportionally to the original cell values. This needs 4 steps, i.e. : 1 . Identifying the traffic volume need to be calibrated; 2. Identifying the OD Matrix Cell need to be calibrated; 3. Distributing the error value to the corresponding OD Matrix cells; 4. Developing Calibrated OD Matrix.

The Validation and the Calibration is a pair of tasks to be executed in iterative way, depend on the case.
The research should be developed by developing Calibration Method for the case that needs more than 1 calibration calculation. Inwhich, calibrating a traffic volume may unacceptably worsen the other traffic volume.

\section{ACKNOWLEDGEMENT}

This paper present the preliminary research work in preparation for developing the Samarinda City Transportation Model.

\section{REFERENCES}

[1] BalitbangHub. "Studi Penyusunan Tataran Transportas Nasional". Laporan Akhir. Badan Penelitian dan Pengembangan, Departemen Perhubungan. Jakarta. 2005.

[2] Benbow, Nick et al. "Transport for South Hampshire Evidence Based Road Traffic Model Calibration and Validation - Summary Report 4". Report for Transport for South Hampshire. MVA Consultancy. Souht Hampshire. 2011

[3] Gruhl J. \& Gruhl, N. Method and Examples of Model Validation - An Annoted Bibliography. MIT Energy Laboratory Working Papers MIT-EL 78-022WP. Massachussets. 1978.

[4] INRO. EMME 4.2 User Guide. INRO. Westmount. 2014.

[5] Ortuzar, J.D. \& Willumsen, L.G. Modelling Transport. John Wiley \& Sons. New York. 1994

[6] PTV. PTV Visum 15 Manual. PTV AG Group. Karlsruhe. 2015

[7] Suprayitno, Hitapriya. "Metoda Pemodelan Kebutuhan Angkutan Barang Perkotaan - Kasus Kota Surabaya. Simposium FSTPT 2 - Surabaya 2 Desember 1999, Jurusan Teknik Sipil, ITS. Surabaya. 1999

[8] Suprayitno, Hitapriya. "Metoda Penilaian Kualitas Jaringan Jalan Utama di Wilayah Kabupaten”. Disertasi, Jurusan Teknik Sipil, ITS. Surabaya. 2014.

[9] Suprayitno, Hitapriya. "Penyusunan Metoda Perhitungan Mode Distribusi Perjalanan berbasis Data Volume Lalu Lintas pada Kasus Pembebanan All-or-Nothing”. Seminar Aplikasi Teknologi Prasarana Wilayah 2015. ITS, Surabaya, 11 Juni 2015.

[10] Suprayitno, Hitapriya. "Traffic Flow Quality as Part of Network Quality of Sparse Road Network". Procedia Engineering 125, page 564-570. Elsevier. Amsterdam. 2015

[11] Suprayitno, Hitapriya. "Development of A Special Matrix Technic for Road Network Analysis - Case of Identifying Unconnected and Miss-connected Nodes". The 18th FSTPT International Simposium, Bandar Lampung 28 August 2015. University of Lampung. Bandar Lampung. 2015

[12] Tamin, O.Z. Perencanaan, Pemodelan \& Rekayasa Transportasi. Penerbit ITB. Bandung. 2008.

[13] Taylor, D. et al. "Fundamentals of Model Calibration: Theory and Practice. ISPOR 17th Annual International Meeting. Washington, 2 June 2012.

[14] Wegman, Fred \& Everett, Jerry. Minimum Travel Demand Model Calibration and Validation Guidelines for State of Tennesse. Centre for Transportation Research. The Universit y of Tennesse. Knoxville. 
[15] Badan Informasi Geospasial, 2015., "Modul Validasi Peta Rencana Tata Ruang. Modul 1 Sumber Data,". Bogor

[16] Badan Informasi Geospasial, 2015.,'Modul Validasi Peta Rencana Tata Ruang. Modul 2 Sebaran Dan Pemilihan Titik,". Bogor

[17] Badan Informasi Geospasial, 2015., "Modul Validasi Peta Rencana Tata Ruang. Modul 3 Pengukuran GPS,". Bogor

[18] BIG, 2015. "Modul Validasi Peta Rencana Tata Ruang. Modul 4 Orhorektifikasi dan Uji Akurasi,". Bogor 